\title{
DETERMINATION OF THE DOG TEETH COLOR
}

\author{
TIHAČEK-ŠOJIĆ LJILJANA, STANČIĆ I and JELENKOVIĆ ALEKSANDRA
}

Clinic for Prosthetic Dentistry, University of Belgrade, Faculty of Stomatology, Serbia

(Received 17. May 2008))

Tooth color depends on hard tooth tissue structures, above all dentine, and is genetically determinated. Nutritive habits and nutrition patterns during the lifetime can influence the change of crystal structure of enamel and dentine and consequently tooth color. The purpose of this research is to determine the color of dog teeth and to compare it to human tooth color. Standardized color key was used, thus overcoming all three color parameters: main color - hue, satiate - chroma and brightness - value. The obtained results show that both colors of dog and human teeth belong to the same spectrum. Dog teeth more frequently have a darker color which can be connected to the fact that their teeth are more worn and consequently a more intensive diffusion process is undergoing due to the changes in crystal structure because of the newly formed bondings of organic molecules into the crystal structure of the enamel.

Key words: dogs, teeth color, diffusion

\section{INTRODUCTION}

In humans, teeth color has a mostly esthetic and psycho-social value because it is one of the most distinctive characteristic of a human smile. Accordingly, a special meaning is attributed to it in contemporary dentistry, especially in reconstructive procedures, as well as in everyday life. Lower vertebrates and reptiles are homodonts, which means that they have only one kind of teeth of a simple form and differ only by size. They can make only one-axle movements due to the lack of precise occlusion. In dogs there is no mastication, only food devouring. The mammal dental system evolved in more types of teeth, therefore they are called heterodonts. Carnivores (carnivorae), although heterodonts, can not make lateral movements of the mandible. In that way, among dogs there is a strong intercuspation, stipulated by an antecedent evolutionary pattern (devouring) without the possibility of lateral movements, i.e. mastication (Geerling, 2001). The canine teeth are dominating by their function and appearance. Their basic function being food ripping which enables efficient catching and processing of the prey. However, food processing is not their only purpose. In carnivores they play an important part in attacking and defense and in intimidating the prey or potential attackers, so that even the picture of a growling 
dog is frightening. On dogs exhibitions special care is attributed to canine teeth. The change of teeth color suggests the presence of caries, calculus or a systematic disease of some kind. Dogs' permanent dentition consists of 12 incisors, 16 premolars, 10 molars, and 4 canine teeth.

Teeth color depends on the specific composure of tooth tissue minerals. Hard tooth tissues visible in the oral cavity under physiological conditions are dentine and enamel. Dentine is the primal source of tooth color, more opaque than the enamel and therefore light reflecting. The enamel, which covers the dentine, consists of over $90 \%$ of an inorganic component - hydroxyapatite crystals which give it the quality of the hardest tissue in the human organism, and of a small percentage of organic matrix. The light refraction indices of the enamel prism and enamel matrix are different. Because of that light rays decompose by reflection and refraction creating a translucent effect and color depth (Joiner et al., 2008). When the light falls on a tooth, a part of it reflects itself and the rest penetrates the enamel and becomes absorbed. The portion of light that penetrated the dentine is partly absorbed and partly reflected to be decomposed again in the enamel. If there is a lack of dentine in some part, as is the case on the incisal edges of the frontal teeth, a segment of light goes through the enamel and becomes absorbed in the oral cavity and consequently the tooth is more translucent in the incisal third than the tooth parts facing the gum.

In humans in the Balkan region colors of the A spectrum prevail, hence they are the most used in dental reconstructive procedures. Canine teeth by default are of somewhat darker nuance for two reasons. The first is their larger dentine volume compared to that of the incisors, which makes it less transparent than enamel and therefore reflects the light. Also, the shape of the vestibular surface of the canine teeth is specific due to its position in the dental arch and is divided into two areas, both towards intercanine and transcanine sectors (Joiner, 2004).

The crystallographic and colorimetric analysis of tooth enamel, which was conducted in previous studies, confirmed that the composition of hydroxyapatite enamel crystals does have an influence on teeth color (Tihaček-Šojić et al., 1997; 1998). The surface of enamel is permanently exposed to the influence of a large quantity of different substances originating from saliva, food, dental plaque and foreign material, which makes diffusion from the enamel surface towards inner parts highly intense. Diffusion represents an internal mixture of gases, liquids and solid bodies. Enamel tissue, which is reduced in the process of natural abrasion, as well as via dental procedures on humans, is exposed to the influence of foreign agents that can change its composition. The hydroxyl ion from hydroxyapatite can be replaced with the chlorine ion into chlorapatite, with the fluorine ion into fluorapatite and with the carbonate ion into dactyl. In accordance with these data, the effect of changes in organic and non-organic components of enamel and dentin on the color of teeth might be expected.

Hydroxyapatite can be found in nature as an ore which, depending on the habitat, can be black, white, brown or the color of sand, while the chemical composition remains the same. Mineralogy can not explain this phenomenon, hence the tooth color genesis is also not known. Up to date research did not deal with mammal teeth color, and even contemporary dentistry only recently begins to 
take teeth color as a research subject. The aim of this study is to determine dog teeth color and to compare it to human teeth color. The same histological structure and embryological development of human and dog teeth, but different nutrition patterns, chewing cycle and absence of oral hygiene, can be the causes of potential differences.

\section{MATERIAL AND METHODS}

Teeth color in dogs has been determined based on a sample of 100 dogs, i.e. 50 purebred dogs and 50 mixed breed dogs, on the territory of Belgrade. The color of all teeth has been determined. Dogs were between one and three years old.

The color has been determined based on the standardized color key (VITA), which includes the following colors: A1, A2, A3, A3,5, A4, B1, B2, B3, B4, C1, C2, $\mathrm{C} 3, \mathrm{C} 4, \mathrm{D} 1, \mathrm{D} 2, \mathrm{D} 3, \mathrm{D} 4$. The letter refers to the spectrum to which the color in question belongs to and the number refers to the hue of the color in question, namely, to which degree a certain color belongs to light or dark colors. The smaller number stands for lighter color. Three dentists participated in this color determination process and they mutually interchanged in order to make results as precise as possible, bearing in mind the fact that the eye becomes less sensible to hues of the yellow spectrum after seeing 10-15 teeth. The survey has been conducted in daily light, from 11 a.m. to noon, in a room facing north. Dogs' mouths were held opened with a help of metal holders. Thus a good visibility of the color of teeth has been achieved with a help of a non-invasive method. The data on the color of teeth of the human population were obtained by the determination of color with an identical color key. Fifty patients, between 40 and 50 years old, who visited the Clinic for Dental Prosthetics and the Clinic for Tooth Diseases of the Faculty of Dentistry of the Belgrade University in November and December of 2007, have been included in this part of the survey. Patients had natural teeth, without prosthetic supplements and they were not using chemical teeth whiteners.

The second part of the survey covered 50 dogs over 10 years of age, having teeth color identified in the abovementioned manner. This part of the research also covered 50 individuals aged over 85 , using the same criterion for selecting the patients. compared.

All the data was entered into charts, statistically processed and then

RESULTS

Dogs aged between 1-3 and humans aged between 40-50

When it comes to the total number of inspected incisors and canine teeth in dogs, the colors of $A$ spectrum are predominantly represented with $82.08 \%$, whereas the colors of other spectra are represented to a significantly smaller degree (Figure 1). However small in degree, there are nuances represented such 
as B4 $(4.17 \%), \mathrm{C} 2(0.42 \%)$ and C1 $(0.42 \%)$ which are normally not found in people of this region. The darkest nuance of the spectrum - A4 (20.83\%) is significantly represented within the most represented $A$ spectrum. When it comes to the results related to the color of frontal teeth of the human population, the colors of $A$ spectrum are dominant with some $58.94 \%$. The D spectrum comes second in terms of representation, totaling $33.68 \%$ and was found significantly more often in comparison to dogs.

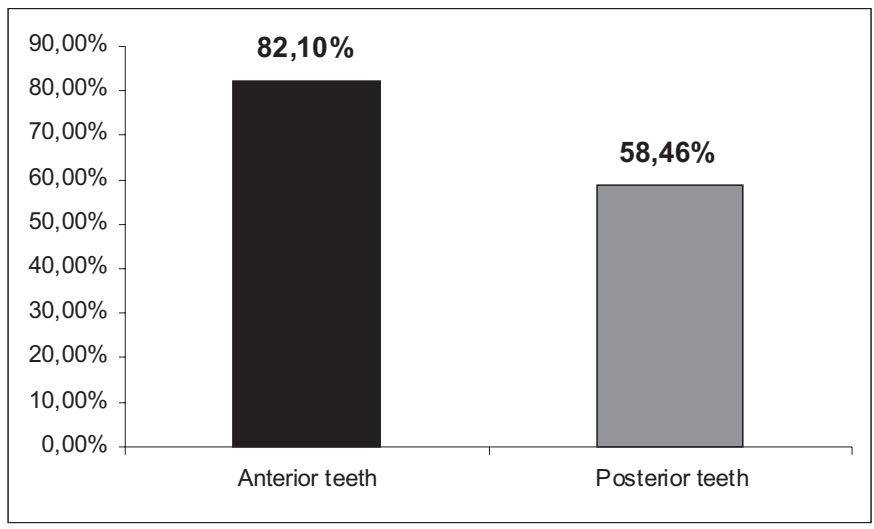

Figure 1. Spectrum A for teeth colors frequency in dogs

Attempting to compare the brightness of frontal teeth in dogs and people, which is difficult since we are dealing with various nuances of different color spectra, representation of light nuances of each spectrum (A1, A2, B1, B2 and D2) was added, resulting in the following findings: light nuances are represented with $16.6 \%$ in dogs, whereas the percentage in humans totals $20 \%$, which is not

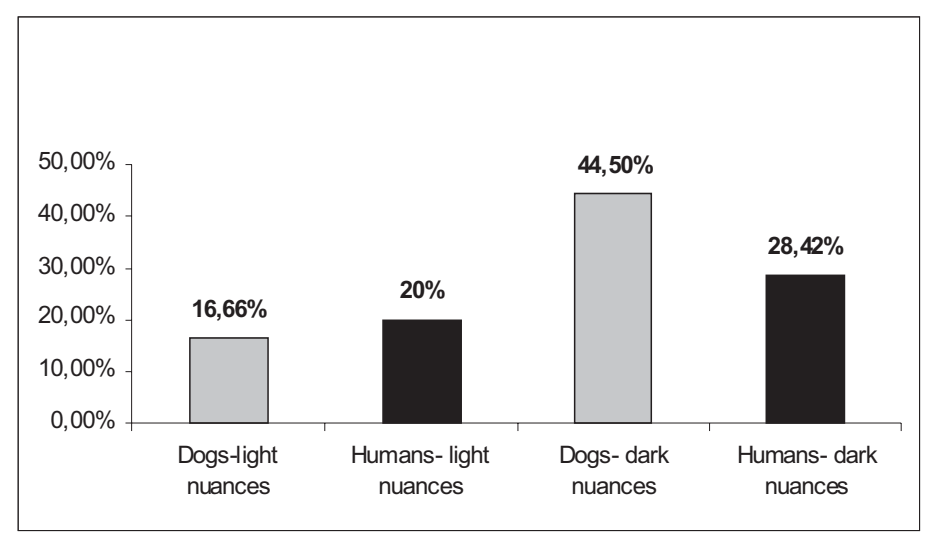

Figure 2. Frequency of teeth color light and dark nuances in dogs and humans 
significantly higher. However, the representation of dark nuances (A3.5, A4, C4 and B4) in dogs totals $44.50 \%$, while the percentage in humans is significantly lower $28.42 \%$, meaning that the nuances of middle brightness are predominant in humans, such as $\mathrm{A} 3$, whereas colors darker by two nuances are predominant in dogs, such as A3.5 and A4 (Figure 2).

When results found in purebred dogs and mixed breed dogs are compared, a conclusion can be drawn that these results do not differ significantly. Namely, the representation of light nuances in purebred dogs equals $15.25 \%$ and/or $14.75 \%$ in the case of mixed breed dogs, the findings are not much different when it comes to dark nuances. The representation of dark hues in purebred dogs equaled $60.86 \%$ and/or $64.13 \%$ in case of mixed breed dogs (Figure 3).

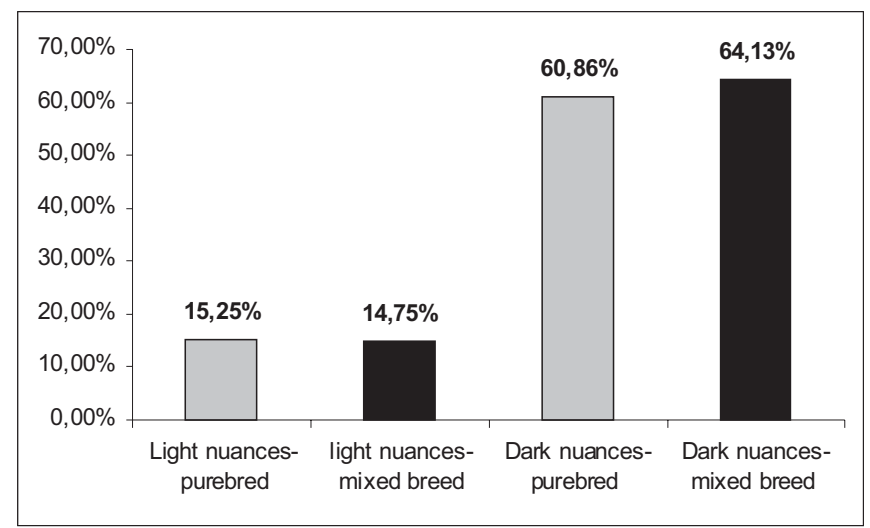

Figure 3. Frequency of light and dark nuances in purebred and mixed breed dogs

In the case of the human population, it is not unusual that canine teeth are darker by several nuances than incisors, which is also indicated by the findings demonstrating that $71.86 \%$ canine teeth are darker than incisors, most commonly by a nuance of the same spectrum. The total of $12.50 \%$ inspected canine teeth were of the same nuance as the incisors, and the same percentage applies in cases when the canine tooth is darker and of another spectrum, which is why they may not be directly compared with incisors (Figure 4). The minimum number of canine teeth is of a lighter nuance than incisors (3.13\%). As opposed to these findings, it is not a rule that dogs' canine teeth are darker in comparison to incisors. These results were found in $25 \%$ of the cases, incisors were lighter in $5 \%$ of the cases and they were of the same nuance as incisors in as much as $70 \%$ cases (Figure 5).

Similar to the situation with the front teeth, lateral teeth both in dogs and humans are predominantly of A spectrum hue (dogs $58.46 \%$, humans $53.21 \%$ ). When it comes to the color brightness, dark nuances are significantly more often represented in cases of lateral teeth of dogs - as much as $56.16 \%$, while the percentage in humans is significantly lower $-21.10 \%$. 


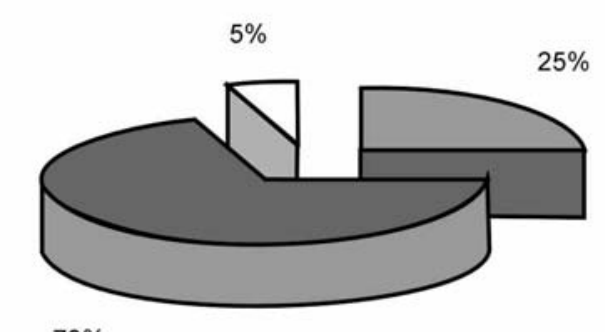

Caninus with darker color then incisors

$70 \%$

Figure 4. Comparison of canine teeth and incisors color in dogs

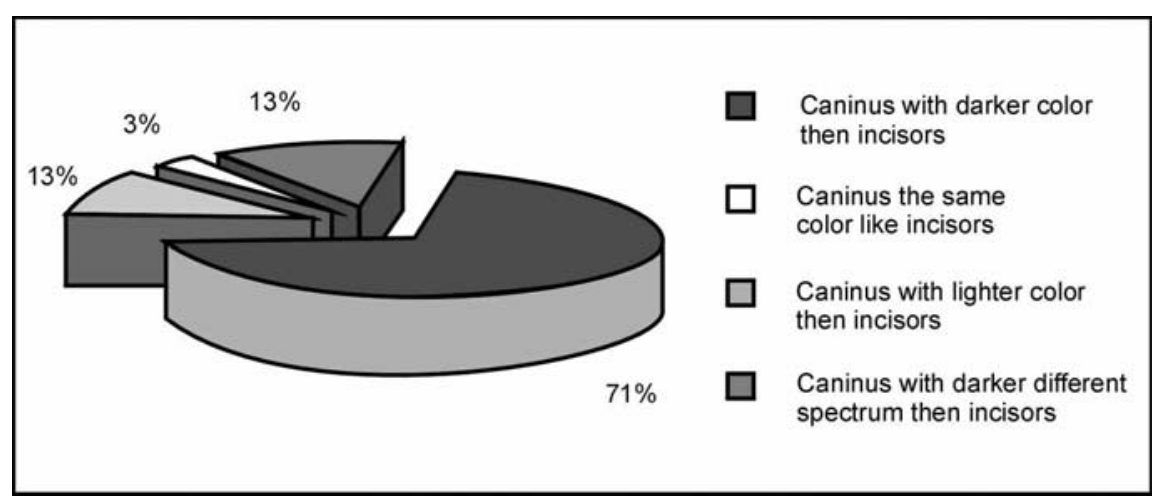

Figure 5. Comparison of canine teeth and incisors color in humans

Dogs over 10 Years of Age and Humans over 85 Years of Age

The findings indicate that aged dogs and humans have slightly darker discoloration of teeth and/or higher representation of darker nuances, in particular the darkest nuance of the A spectrum - A4. Light nuances in dogs over 10 years of age are represented in as much as $18.35 \%$, while dark ones are represented in $35.43 \%$ cases. The A4 nuance is represented with a $15.22 \%$ rate. Lighter nuances are on average predominant in the case of humans aged over 85 , which are still darker in comparison to the middle-aged individuals, since lighter nuances are found in $10.25 \%$ and darker nuances are found in $71.75 \%$ cases. The A4 color was represented in $31.86 \%$ cases (Figures 6 and 7 ). 


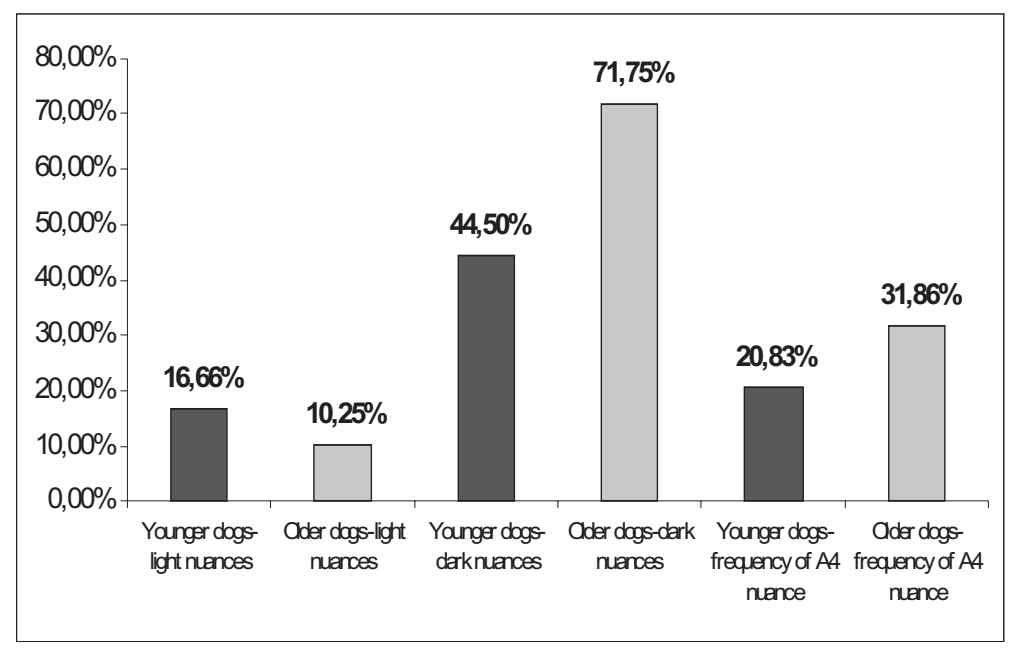

Figure 6. Frequency of light and dark teeth color nuances in dogs aged 1-3 and over 10 years

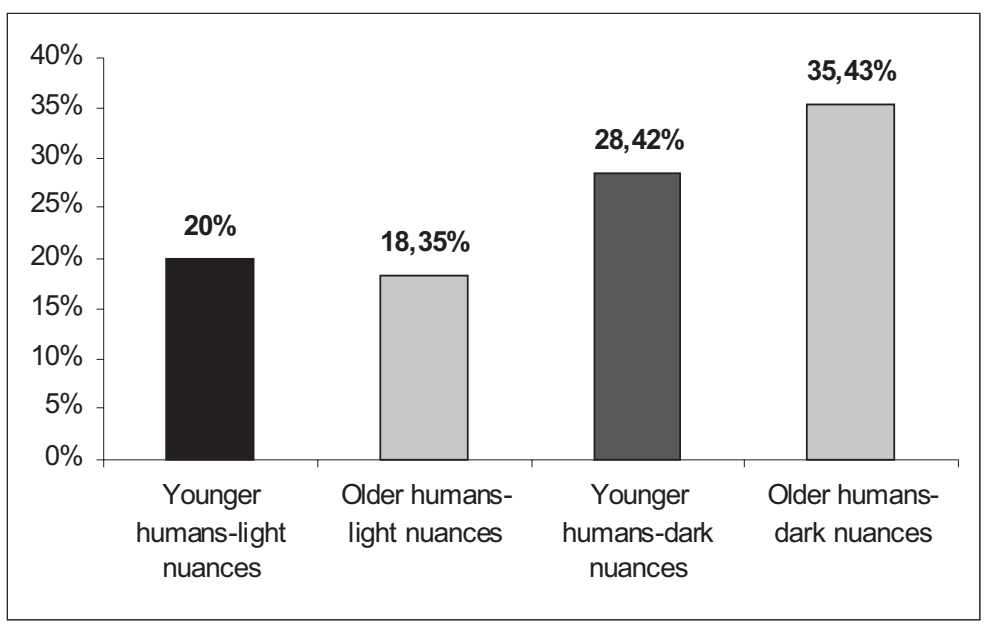

Figure 7. Frequency of light and dark teeth color nuances in humans aged 40-50 and over 85 years

\section{DISCUSSION}

Domination of the same A spectrum, both in humans and dogs, can be explained with the same structure of the hard dental tissues which is present in all developed mammals, and with the same mechanism of embrional development of dental tissues. Differences of the changed colors parameters: hue, chroma and 
value are a consequence of exterior factors such as abrasive and pigmented food, usage of tooth paste with bleachers. In dogs, chemical devices have no influence, but abrasive food is more frequently used comparing to people.

In dogs canines are darker then incisors. This could be explained by some further researches which could analyze dog's dentine and enamel volume and compare it to humans.

It was expected that older individuals, both in human and dogs, have darker nuances of teeth color, because pigments and abrasive food have cumulative effects during the lifetime and change tooth color to darker.

Periodontal disease is the most common oral disease in dogs and leads to progressive inflammation and destruction of the tissues supporting the teeth. Loss of teeth may seriously damage dogs' health and lead to death because there is no adequate prosthetics treatment which can be applied in dogs. In addition to oral pain and tooth loss, periodontal infections can spread systemically and may adversely affect various organs, including the heart, kidneys, and liver (DeBowes et al., 1996). In dogs, age, diet, chewing habits, occlusion and size can affect the severity of periodontal disease. Changed tooth colour, especially darker hues, can manifest the presence of bacterial plaque and calculus, gingivitis and periodontitis (Carmichael, 2006). Hennet et al. (2006) found a great prevalence of plaque accumulation in seven-month old Beagle dogs, but with intact teeth and no visible calculus accumulation. Using Logan \& Boyce index system they found that the plaque coverage and thickness scorings were significantly greater on the gingival part than on the coronal part of teeth. This is in agreement with the natural development of periodontal disease which starts with plaque accumulation along the gingival margin and subsequently extends to the crown. Besides tooth colour, bad breath can also be one of the signs of periodontal disease. Halitosis of a 7 year old female greyhound was the consequence of many ulcerative stomatitis lesions adjacent to areas of calculus accumulation. It is proved that some dogs with oral mucosa ulcerations may have a hyper immune response to plaque and calculus (Bellows, 2002).

In skeletal remains of dogs from Neolithic period (Van-Yoncatepe Necropolises, Turkey), evidences of periodontal diseases, abrasion and enamel hypoplasia were found (Onar et al., 2002). Authors found extremely worn teeth, so that the pulp cavity became visible as a result of excessive dentin wear and there were prevalent signs of periodontal disease in very young or middle-aged dogs. Widespread alveolar recession accompanied by symptoms of periodontal disease was detected in six skulls.

Tooth tissue abrasion is greater in dogs then in humans due to a different dietary regime. Diffusion throug an abraded surface is very intensive. TihačekŠojić (2005) has proved that organic spin markers penetrate faster and deeper when enamel is reduced and left without protection, no mater if it is caused by abrasion or dental treatment. Process of organic spin marker movement through the enamel is controlled by diffusion mechanisms and chemical bonding of the marker molecule to the enamel structure. Also, organic molecules, in addition to the diffusion process through the interprysmatic spaces of enamel tissue, have a crucial role in the changes of the crystal grid size, due to binding of organic parts 
of molecules in the enamel crystal structure. Permanent oscillations of the number of diffunded marker molecules in the enamel, show that binding to enamel structure is ongoing, and it is the result of substitution and resupstitution of $\mathrm{OH}$ ions from the enamel crystal grid with organic, inorganic molecules or various dental materials (Marx et al., 2007). Tihaček-Šojić and Đurić (1998) have determined by crystallographic and colorimetric analysis of the anthropological samples of enamel that enamel structure influences tooth color. Diffusion and change of the inorganic components of apatite crystals, namely, substitution of hydroxyl ions with chloral, fluoride, and carbonate ions, influence hue and chroma of tooth color. In that way, it can be concluded that, among other before mentioned factors, changes in the enamel crystal grid is a consequence of active diffusion througs abraded surfaces of dogs' teeth can be considered responsible for darker teeth nuances in dogs.

Address for correspodence:

Prof dr Ljiljana Tihaček-Šojić

Clinic for Prosthetic Dentistry

Faculty of Stomatology

Rankeova 4

11000 Belgrade, Serbia

\section{REFERENCES}

1. Geerling E, Langenbach J, Theo MG, van Eijden J, 2001, Mammalian Feeding Motor Patterns, American Zoologist, 41, 6, 1338-51.

2. Joiner A, Hopkinson A, Deng I, Westland Y, Stephen, 2008, Review of tooth color and whiteness, $J$ Dent, 080102, 36, 2.

3. Joiner A, 2004, Tooth color: a review of the literature, J Dent, 040102, 32, 3.

4. Tihaček-Šojić LJ, Milićević V, Đurić-Srejić M, 1997, Crystallographic and colorimetric analysis of dental enamel, Dent Anthropol Newslett, 11, 2

5. Tihaček-Šojić LJ, Đurić M, 1998, Analysis of the optical properties of medieval enamel, Dent Anthropol, 13, 1.

6. DeBowes LU, Mosier D, Logan E, 1996, Association of periodontal disease and histological lesions in multiple organs from 45 dogs, $J$ Vet Dent, 13, 2, 57-60.

7. Daniel Carmichael, 2006, Veterinary Medicine, Lenaxa, 101, 10, 640.

8. Hennet $P$, Servet $E$, Salesse $H$, Soulard $Y, 2006$, Evaluation of the Logan \& Boyce plaque index for the study of dental plaque accumulation in dogs, Res Vet Sci 80, 175-80.

9. Bellows J, 2002, Veterinary Medicine, Lenaxa, 97, 2, 86.

10. Onar V, Armytak A, Belli O, Konyar E, 2002, Skeletal Remains of Dogs Unearthed from the VanYoncatepe Necropolises, Int J Osteoarchaeol, 12, 317-34.

11. Tihaček-Šojić LJ, 2005, Possibilities of binding organic molecules within the enamel crystal structure in dogs, Acta Veterinaria, Beograd, 55, 2-3, 227-36

12. Tihaček-Šojić LJ, 2005, Extent of diffusion of organic molecules in enamel tissue of dogs, Acta Veterinaria, Beograd, 55, 1, 53-68.

13. Marx J, Steenkamp G, van Heerden WF, Pretorius Boy ESC, 2007, Scanning electron microscopic study of the dentinal tubules in dog canine teeth, $J$ Vet Dent, 24, 2, 86-9. 


\title{
ODREĐIVANJE BOJE ZUBA KOD PASA
}

\author{
TIHAČEK-ŠOJIĆ LJILJANA, STANČIĆ I i JELENKOVIĆ ALEKSANDRA
}

\section{SADRŽAJ}

Boja zuba zavisi od sastava tvrdih zubnih tkiva, pre svega dentina i genetski je određena. Obrazac ishrane i nutritivne navike mogu u toku života putem difuzije uticati na promenu kristalne strukture gleđi i dentina a posledično i na boju zuba. Cilj rada je utvrditi boju zuba pasa i uporediti je sa bojom zuba ljudi. Korišćen je standardizovan ključ za boje kojim je moguće obuhvatiti određivanje sva tri parametra boje: osnovnu boju - hue, zasićenost - chroma i svetlinu - value. Dobijeni rezultati pokazuju da boja zuba i pasa i ljudi u najvećem broju slučajeva pripada istom spektru. Kod pasa su zastupljenije tamnije nijanse, što se dovodi u vezu sa većom abradiranošću površina njihovih zuba i intenzivnijom difuzijom i promenama dimenzija kristalne rešetke zbog vezivanja organskih delova molekula u strukturi kristala gleđi. 